\section{OP-109放射線膀胱炎患者に対する高気圧酸素 治療の長期成績}

\begin{abstract}
四街道德洲会病院泌尿器科 ${ }^{1)}$ ，山形県立置賜総合病院泌 尿器科2), 千葉徳洲会病院3), 千葉大学医学部泌尿器 科 ${ }^{4)}$, 富山医科薬科大学泌尿器科 ${ }^{5)}$

中田 瑛浩 ${ }^{1}$, 久保田 洋子 ${ }^{2}$, 原野 和芳 ${ }^{3)}$, 大嶋 秀一 ${ }^{3)}$, 市川 智彦 ${ }^{4)}$, 布施 秀樹5), 山口 健哉 ${ }^{1)}$, 山中 弥太郎 ${ }^{13}$

放射線膀胱炎は難治性疾患の一つであるが、Weiss らにより高気 圧酸素 (HBO) 治療が有効なことが最初に報告され、多くの国々で 施行されるようになった。しかし、難治例、再発例もあることが最 近、報告される様になった。演者らは 6 例の子宮癌患者に HBO 治療 を施行し、その有效性を報告したが、今回、25例の放射線膀胱炎患 者に HBO 治療を行い、約 10 年間フォローした。長期フォローの成 績は少なく、その結果も controversial である。治療経験を報告する。 患者は $63 \pm 2$ 歳、HBOは 2 絶対圧で、 1 回 90 分、合計 $51 \pm 2$ 回を 施行した。一部の難治、再発例には $25 \pm 1$ 回を追加した。すべての 患者で subjective symptom；頻尿、排尿痛、尿失禁は $88 \%$ 、92\%、 $96 \%$ が改善した。objective symptom ; 輸血施行率、尿中赤血球数、 膀脱鏡所見は $100 \% 、 84 \% 、 91 \%$ が改善した。難治例、再発例群は 易治癒例に比し被曝線量が高く $(81 \pm 6: 60 \pm 2 \mathrm{~Gy})$, 発症までの期間 が短く $(1.6 \pm 0.4: 3.1 \pm 0.5$ 年)、膀胱組織の malondialdehyde 含量が 高いことが判明した。輸血は 6 年後には全例不要となった。本疾患 は高齢者、高被曝患者、重篤血尿患者、被曝後の早期症状発症患者 にも長期の治療で改善が期待でき、再発例にも intermittent therapy を施行することで好成績が得られると推測された。
\end{abstract}

\section{OP-110 腹腔鏡下vs 恥骨後式前立腺全摘除 術一同一施設、同一術者による比較検 討一}

\section{中津第一病院泌尿器科}

溝口 裕昭, 牟田口 和昭, 梶原 充, 花田 麻里 目的：同一施設、同一術者の手術成績から腹腔鏡下前立 腺全摘除術の有用性を検討する。対象：2002 年 3 月から 2005 年 8 月までに中津第一病院泌尿器科において施行 された前立腺全摘除術 120 例のうち同一術者による腹腔 鏡下手術 28 例（A 群）と開放手術 25 例（B 群）を対象 とする。A 群 B 群の年齢はそれぞれ 67.8、66.3 歳、PSA は $14.0 、 10.7 \mathrm{ng} / \mathrm{ml}$ 。方法：A 群は 5 ポートにより経後腹 膜的アプローチにて順行性に摘出、膀胱尿道吻合は原則 として連続縫合とした。B群は恥骨後式にて逆行性に摘 出、膀胱尿道吻合は原則として 6 針結節縫合とした。結 果：A 群の 2 例は開放手術に変更された。 $\mathrm{A}$ 群 $\mathrm{B}$ 群の手 術時問はそれぞれ 292、156 分 $(\mathrm{p}<0.0001)$ 、出血量は 999、 $951 \mathrm{ml}$ 、輸血量は $871 、 784 \mathrm{ml}$ 、組織重量は $33 、 36 \mathrm{~g}$ 、食事開 始は2.0、2.5 日、鎮痛剂使用回数は 1.75、1.56 回、カテーテ ル留置期間は $11.8 、 13.1$ 日。尿禁制率 $(1 、 3 、 6 、 12$ ケ月) は $\mathrm{A}$ 群 $18 、 36 、 79 、 86 \% 、 \mathrm{~B}$ 群 $36 、 58 、 62 、 75 \%$ 。尿道狭窄やへ ルニアなどを含む術後合併症は $46 、 48 \%$ 。絬論：今回の 比較検討では手術時間や早期の尿禁制率等において腹腔 鏡下前立腺全摘除術の優位性を引き出すことはできな かった。さらなる症例の積み重ねが必要である。

\section{OP-111 体腔鏡下前立腺全摘除術後の尿禁制回 復時期についての検討}

\begin{abstract}
東海大学医学部外科学系泌尿器科1”, 東海大学東京病院 泌尿器科 ${ }^{2)}$, 静岡市立清水病院泌尿器科 ${ }^{3)}$

白井 幸男 ${ }^{1)}$,島 正則 ${ }^{1)}$, 小林 泰之 ${ }^{1)}$, 星 昭夫 ${ }^{1)}$,

花井 一也西川 全海 ${ }^{1}$, 花井 禎 ${ }^{1}$, 兵地 信彦 ${ }^{1)}$,

松下 - - 男 ${ }^{2}$, 稲士 博右 ${ }^{3)}$, 寺地 敏郎 ${ }^{1)}$

【目的】体㬶鏡下前立腺全摘除術（Laparoscopic Radical Prostatectomy：LRP）に㧍けるDVC 処理法や膀胱尿道吻合法が術後早期の尿 禁制回復に影響するか検討を行った。【対象と方法】2002 年 4 月から 2005 年 9 月までに東海大学病院と関連施設において LRP を施行した 134 例のうち経過が追えた 123 例を対象とした。手術手技は 3 群（1 群：DVC 結紫・吻合部固定なし、2 群: DVC 無結紮・吻合部固定あ り、3 群: DVC 無結㮡·pudendal vessel 温存・吻合部固定あり)に分 類し、それぞれの尿禁制回復時期について検討を行った。【結果】年 齢は65歳 \pm 5.9 、観察期間は 11 ヶ月 \pm 8.9 。手術手技 1 群は 29 例 (23.6\%)、2 群は54 例 $(43.9 \%) 、 3$ 群は 40 例 $(32.5 \%)$ であった。全 体の尿禁制回復率は $88.0 \%$ で術後 1 週間 $/ 1$ ケ月 $/ 3$ ケ月/ 6 ケ月 $/ 2$ ケ 月は $34 / 15 / 21 / 11 / 7 \%$ であった。術後 1 年以上 $\mathrm{pad}$ を要している症例 は 5 例 $(4.5 \% 、 1$ 群 2 例、2 群 3 例) に認められた。手術手技別の早期 (3ヶ月以内) 改善率は 1 群 $65 \% 、 2$ 群 $72 \% 、 3$ 群 $70 \%$ であった。特に 3 群ではカテーテル拔去早期 (1 週間以内) に改善する症例が多く見ら れた（1群：6例 $20.7 \% 、 2$ 群：12 例 $22.2 \% 、 3$ 群：23例 $57 \%$ )。 これまでの検討では年齢や勃起神経温存の有無との関連は見られず 早期の尿禁制回復には手術手技が重要であると考えられた。
\end{abstract}

\section{OP-112 腹腔鏡下前立腺全㵝除術における病理 学的治療成績向上と尖部処理の工夫}

\section{日本医科大学泌尿器科 \\ 近藤 幸尋, 濱崎 務, 松沢一郎, 鈴木 康友,}

㸉藤 友香, 高橋 亮, 木村 剛, 吉田 和弘, 西村 泰司 【日的】腹腔鏡下前立腺全摘除術を我々は 2000 年以来 180 例を経験しているが、本術式の現状分析としての Oncological outcome と尖部処理法に関して検討した。 【方法】 2000 年より 2005 年 6 月までの Partin nomogram でリンパ節転移の確率が $3 \%$ 以下と予想される限局性前 立腺癌かつ患者希望により施行された 180 例を対象とし た。術式は経腹膜アプローチを全例に施行した。手術標 本の病理学的検討とPSA failure を検討した。【成績】病 理学的検討では被膜浸潤を $16.4 \%$ 、断端陽性を $14.7 \%$ に 認めた。観察期間は比較的短いものの PSA failure は $2.9 \%$ と良好な結果を得ている。前立腺尖部の処理はその 形状により困難な場合も少なくないが、腹腔鏡下の手術 に执いては前立腺の被膜を全方向より確実に露出し尿道 に向かい剥離していくことを心掛けている。それ故断端 陽性率も有意に低下している。【結論】 PSA failure が低 いことより cancer control は良好であり、適応が若干こ となるものの一般の開腹式の前立腺全摘除術に比較して も cancer control 良好な術式として確立していく可能性 が示唆された。 